\title{
Computercriminaliteit en accountant
}

De invloed van verschijningsvormen van computercriminaliteit op de accountantscontrole, of ... wat de accountant kan en moet met zoiets als computercriminaliteit

Mr. Drs. J.T. Olieman

\section{Inleiding}

Per 1 maart 1993 is de Wet Computercriminaliteit in werking getreden. Dit trekt de aandacht van de accountant, niet alleen omdat computercriminaliteit invloed kan hebben op de getrouwheid van de jaarrekening, maar ook omdat de accountant expliciet genoemd wordt in die Wet Computercriminaliteit.

Dit artikel gaat in op:

- de totstandkoming en achtergronden van de Wet Computercriminaliteit;

- wat van de accountant verwacht mag worden, wanneer hij verschijningsvormen van computercriminaliteit tegenkomt;

hoe aandacht voor computercriminaliteit ingepast kan worden in de accountantscontrole.

\section{De totstandkoming en achtergronden van deWet Computercriminaliteit}

Wie de Wet Computercriminaliteit in het wetboek probeert op te zoeken, komt bedrogen uit. De Wet Computercriminaliteit bestaat namelijk uit een aantal aanpassingen van het Wetboek van Strafrecht (WvS) (materieel strafrecht), het Wetboek van Strafvordering (formeel strafrecht), ${ }^{1}$ de Wet Telecommunicatievoorzieningen en het Burgerlijk Wetboek (BW). De voortschrijdende toepassing van informa- tietechniek heeft de vraag opgeworpen of misbruik van de informatietechniek afdoende beperkt kan worden. Hiertoe heeft de minister van Justitie in 1985 de Commissie Computercriminaliteit ingesteld, ook wel bekend onder de naam: 'Commissie Franken'

Hoewel de taakopdracht gericht was op de toereikendheid van het strafrecht, is niet nagelaten nadruk te leggen op goede preventieve beveiliging van geautomatiseerde systemen door de potentiële slachtoffers. Het strafrecht kan slechts dienen als een sluitstuk op de bestrijding van (computer)criminaliteit. De commissie heeft in 1987 het rapport 'Informatietechniek en Strafrecht' uitgebracht. In dit rapport werd het belang van wetsaanpassingen beargumenteerd, naast verdere suggesties om de kwaliteit van de beveiliging in bedrijven en instellingen te verbeteren en de aangiftebereidheid? ${ }^{2}$ te vergroten. In het rapport is de principiële keuze gemaakt om het arrest van het Gerechtshof van Arnhem van 27 oktober 1983 (NJ 1984, 80) niet te volgen. Dit houdt in dat 'gegevens' als wezenlijk verschillend gezien worden als 'goederen'. Door deze principiële keuze was de noodzaak voor een ingrijpende wetsaanpassing geboren. Op 16 mei 1990 is het wetsontwerp computercriminaliteit (Kamerstukken II 1991-1992, 21 551, nr. 2) ingediend. Ruim twee jaren is het

Mr. Drs. J.T. Olieman was jurist, econoom en registeraccountant. Zijn jonge leven werd geteisterd door twee zeer ernstige ziekten. Hij overleed op 18 juni 1994 


\section{MAB}

wetsontwerp in behandeling geweest. De wet is onder de naam 'Wet van 23 december 1992' op 1 maart 1993 in werking getreden (Staatsblad 1993 33).

De Wet Computercriminaliteit bevat wetsaanpassingen die erop gericht zijn om meer verschijningsvormen van computermisbruik strafbaar te maken en de opsporing en het vergaren van bewijs te vergemakkelijken.

Voor de accountant is een aantal van deze wetsaanpassingen van belang en wel in het bijzonder de eis van art. 2:393 lid 4 BW: De accountant wordt verplicht om na uitvoering van de jaarrekeningcontrole in het verslag aan de raad van commissarissen en het bestuur tenminste melding te maken van zijn bevindingen met betrekking tot de betrouwbaarheid en continuïteit van de geautomatiseerde gegevensverwerking.

Dit wetsartikel heeft slechts indirect iets te maken met computercriminaliteit. Het is namelijk een flauw aftreksel van de aanzet van de Commissie Franken om drempels op te werpen tegen nonchalance ten aanzien van de beveiliging van gegevensstromen. Bij deze aanzet zouden zeer complexe regels gesteld moeten worden aan rechtspersonen. Een tot in details uitgewerkte regeling zou onhandelbaar worden. Daarom is bij de voorstellen gedacht aan de volgende varianten:

1 Een oordeel van de accountant in het kader van de jaarrekeningcontrole omtrent de beveiliging van de geautomatiseerde gegevensverwerkende systemen.

2 Een oordeel van een deskundige (accountant of EDP-auditor) met betrekking tot de betrouwbaarheid en continuilteit van de geautomatiseerde gegevensverwerking

3 De verklaring over de betrouwbaarheid en continuilteit van de geautomatiseerde gegevensverwerking wordt door de directie opgenomen in het jaarverslag van de onderneming. Over die verklaring dient de accountant zich uit te laten.

Termen als beschikbaarheid, integriteit en exclusiviteit waren reeds gebruikt als trefwoor- den om de belangen aan te geven die kunnen worden geschaad door de toenemende afhankelijkheid van de geautomatiseerde gegevensverwerking en de daaruit voortvloeiende kwetsbaarheid. Daarom zijn hier de termen betrouwbaarheid en continuïteit gebruikt. ${ }^{3}$ Gekozen is voor de derde variant met het argument dat daarmee tot uitdrukking wordt gebracht dat de verantwoordelijkheid voor de mate en kwaliteit van beveiliging bij de directie van de vennootschap ligt.

De commissie had de begrippen betrouwbaarheid en continuiteit als volgt gedefinieerd: betrouwbaarheid is een redelijke zekerheid dat de verwerking van gegevens juist, volledig, tijdig en op geoorloofde wijze geschiedt en continuilteit is een redelijke zekerheid dat de gegevensverwerking ongestoord voortgang zal kunnen vinden, dat wil zeggen ook na ernstige storingen binnen redelijke termijnen kan worden hervat. De minister van Justitie benadrukt in de nota naar aanleiding van het eindverslag het feit dat onder betrouwbaarheid van het systeem eveneens (toegangs-)beveiliging moet worden begrepen.

Ongeacht of het vaktechnisch gezien verantwoord zou zijn verdergaande eisen te stellen dan nu in art. 2:393 lid 4 BW is gedaan, is het van belang te weten dat de wetgever wel degelijk aan andere varianten gedacht heeft.

De begrippen betrouwbaarheid en continuilteit sluiten niet direct aan op het begrip computercriminaliteit. Daarom is het wellicht van belang om eens nader te kijken naar de verschijningsvormen waarin computercriminaliteit zich kan voordoen.

\section{Confrontatie met verschijningsvormen van computercriminaliteit}

Voor de accountant is bij een nieuw begrip als 'computercriminaliteit' de verschijningsvorm van belang, omdat elke vorm z'n eigen aanpak vereist. Elke aanpak kan vertaald worden naar werkzaamheden die de accountant reeds kent. Zo zal blijken dat er voor de accountant niets nieuws onder de zon is. 
In de Wet Computercriminaliteit wordt een aantal nieuwe delicten aan het Wetboek van Strafrecht toegevoegd: ${ }^{4}$

- misdrijven tegen de veiligheid van de staat (art. 98 en 98a WvS);

- computervredebreuk (art. 138a WvS);

- aftappen van gegevens (art. 139a-e en 441 WvS);

- opzettelijke vernieling van computers e.d. (art. 161 sexies WvS);

- schuld aan vernieling van computers (art. 161 septies WvS);

- vervalsing betaalpassen e.d. (art. 232 WvS);

- 'diefstal' van geautomatiseerde diensten (art. 326c WvS);

- toebrengen van schade aan computergegevens (art. 350a en b WVS)

De toevoeging van de nieuwe delicten is een aanscherping van de strafbaarstelling alleen op punten waar het materiële strafrecht ${ }^{1}$ ontoereikend werd geacht. De opsomming van nieuwe delicten geeft voor de accountant daarom geen systematisch overzicht van de verschijningsvormen van computercriminaliteit. Trouwens, de strafbaarheid van (computer)misbruik is voor een strafrechtjurist meer interessant dan voor een accountant.

Om de verschijningsvormen van computercriminaliteit te inventariseren gaat mijn voorkeur uit naar de categorisering van de Raad van Europa, die ook door Charbon en Kaspersen (1990) gebruikt wordt. Deze categorisering ziet er als volgt uit:

1 computer-gerelateerde fraude;

2 computer-gerelateerde valsheden;

3 toebrengen van schade aan (waaronder wijzigen van) computergegevens en -programma's:

4 computersabotage;

5 onbevoegde toegang;

6 softwarepiraterij waaronder het onbevoegd gebruik van beschermde programma's;

7 onbevoegd onderscheppen van computergegevens

8 chips-piraterij;

9 computerspionage;

10 'diefstal' van geautomatiseerde diensten
Deze categorisering zal nader worden uitgewerkt voor toepassing in de accountantspraktijk. Bij deze indeling wordt ingegaan op de gevolgen van computercriminaliteit voor de cliënt en welke handelingen van de accountant in zijn algemene functie verwacht mogen worden.

\section{Ad. 1-2 Computer-gerelateerde fraude en valsheden}

Deze beide verschijningsvormen van computercriminaliteit worden samen behandeld, omdat zij zeer verweven zijn. Met de term valsheden wordt bedoeld dat er toevoegingen of wijzigingen in verzamelingen van samenhangende gegevens worden aangebracht, waarbij het de bedoeling is dat die gegevens door anderen als echt worden beschouwd. Bij het wijzigen van een saldo in een cliëntenbestand zal eerder valsheid (in geschrifte) bewezen kunnen worden dan bij het willekeurig invoeren van onjuiste gegevens.

Bij fraude gaan vaak andere vormen van computercriminaliteit vooraf, zoals valsheden, het toebrengen van schade aan computergegevens of -programma's. Computer-gerelateerde valsheden kunnen tot doel hebben fraude mogelijk te maken, maar kunnen ook gericht zijn op het vervalsen of verwijderen van bewijzen van fraude. Voor de cliënt zal het gevolg veelal financiële schade zijn.

De accountant zal net zo handelen als bij andere verschijningsvormen van fraude. De frauderichtlijn kan hierbij als leidraad dienen.

\section{Ad. 3 Het toebrengen van schade aan} (waaronder wijzigen van) computergegevens en programma's

Bij het toebrengen van schade aan computergegevens en -programma's wordt voornamelijk gedacht aan virussen, ${ }^{5}$ Trojaanse paarden, ${ }^{6}$ logische bommen ${ }^{7}$ en wormen. ${ }^{8}$ Aantasting van gegevens door middel van fysieke storingen, bijvoorbeeld elektromagnetische storing of brand wordt wél genoemd, maar verder niet uitgewerkt, mede omdat dit weinig specifiek is voor computers.

Afgezien van de wijze waarop de schade wordt 


\section{MAB}

toegebracht, zal deze verschijningsvorm van computercriminaliteit voor de cliënt veelal uitmonden in financiële schade die veroorzaakt is door stagnering in de verwerking van computergegevens of foute verwerking ervan.

De accountant beoordeelt de hoogte van deze financiële schade.

\section{Ad. 4 Computersabotage}

Onder computersabotage verstaan Charbon en Kaspersen (1990) uitsluitend sabotage door middel van 'logische middelen'. ${ }^{9}$

Het risico van discontinuilteit speelt ook bij fysieke sabotage. Het onderscheid tussen computersabotage door middel van logische middelen en fysieke sabotage is voor de accountant minder relevant.

Het verschil tussen computersabotage en het toebrengen van schade aan (waaronder wijzigen van) computergegevens en -programma's is dat bij computersabotage het systeem als geheel niet meer kan worden gebruikt.

Ook bij computersabotage zullen de gevolgen voor de cliënt veelal bestaan uit financiële schade.

De accountant beoordeelt de hoogte en materialiteit van deze financiële schade.

\section{Ad. 5 Onbevoegde toegang}

Onder onbevoegde toegang verstaan Charbon en Kaspersen (1990) het onbevoegd binnendringen in een computersysteem of -netwerk (computervredebreuk).

De mogelijkheid dat onbevoegden toegang tot het geautomatiseerde systeem kunnen verkrijgen geeft schaderisico's voor de cliënt.

De Wet Computercriminaliteit stelt computervredebreuk strafbaar indien daarbij enige beveiliging doorbroken wordt of toegang verworven wordt door een technische ingreep, met behulp van valse signalen of een valse sleutel dan wel door het aannemen van een valse hoedanigheid. Wat onder 'enige beveiliging', 'valse signalen, sleutel of hoedanigheid' verstaan wordt, zal de voortgaande jurisprudentie hierover moeten uitwijzen. De toelichting van de minister van Justitie kan hier onmogelijk in vooruitzien. De accountant heeft bij de uitvoering van de jaarrekeningcontrole minder te maken met strafbaarheid. Hij heeft te maken met de (mogelijke) schade van computervredebreuk.

De accountant zal de schaderisico's nader onderzoeken en mogelijk adviezen uitbrengen met betrekking tot de toegangsbeveiliging van het geautomatiseerde systeem, in de vorm van organisatorische maatregelen en procedures met betrekking tot administratieve organisatie en de daarmee verband houdende interne controle.

Ad. 6 Softwarepiraterij waaronder het onbevoegd gebruik van beschermde programma's Softwarepiraterij is volgens Charbon en Kaspersen (1990) het illegaal verveelvoudigen, verspreiden of aan het publiek ter beschikking stellen van (auteursrechtelijk) beschermde computerprogramma's. Indien de accountant constateert dat het bedrijf van zijn cliënt een dergelijke (neven)activiteit uitoefent, is de handelwijze conform de frauderichtlijn. Bij inbreuken op het auteursrecht is het voor te stellen dat rechthebbenden claims indienen.

Daarnaast kan er sprake zijn van illegaal gebruik van software, dat wil zeggen dat deze software is verkregen zonder toestemming van de maker of de officiële distributeur van de software. Of gewerkt wordt met legale software-pakketten is vast te stellen aan de hand van de gelduitgang (betalingen). Indien de accountant constateert dat de (juiste) betaling ontbreekt, zal hij in eerste instantie zijn cliënt hiervan op de hoogte stellen. Het risico bestaat dat de licentiehouder een claim indient. Dat risico kan invloed hebben op de liquiditeit en solvabiliteit van de jaarrekening. Aanvullend kan hier op verzoek van de cliënt nader onderzoek verricht worden in de vorm van een bijzondere opdracht (zie ook Hoofdstuk 4).

\section{Ad. 7 Onbevoegd onderscheppen van computergegevens}

Bij onbevoegd onderscheppen van computergegevens is in feite sprake van afluistering van datacommunicatie. Indien de cliënt gevoelige 


\section{MAB}

informatie tussen verschillende systemen uitwisselt, ligt het binnen het kader van de natuurlijke adviesfunctie van de accountant om te adviseren deze informatie te beveiligen door middel van versleuteling (encryptie).

\section{Ad. 8 Chips-piraterij}

Chips-piraterij is het illegaal kopiëren, exploiteren of importeren van een beschermd(e topografie van een) halfgeleiderprodukt. Bescherming geschiedt op basis van art. 2 van de Chipswet (Wet inhoudende regelen inzake de bescherming van oorspronkelijke topografieën van halfgeleiderprodukten). Bescherming kan echter tegenover derden alleen

worden uitgeoefend, nadat de topografie is gedeponeerd en ingeschreven bij het Bureau industriële eigendommen te Rijswijk. Van deze beschermingsmogelijkheid wordt nagenoeg geen gebruik gemaakt. De enige relevante chipsproducent in Nederland bewaart de topografieën in eigen beheer. Andere vormen van chips-piraterij zijn juridisch nagenoeg ongrijpbaar. ${ }^{10}$

De bijdrage van de accountant bij deze verschijningsvorm van computercriminaliteit zou ik als minder relevant willen bestempelen.

\section{Ad. 9 Computerspionage ${ }^{11}$}

In verband met computerspionage merken Charbon en Kaspersen (1990) op dat computerspionage gewone spionage is, met dien verstande dat de informatie waarvan iemand onbevoegd kennis neemt, is opgeslagen in een computersysteem. Beveiliging tegen computerspionage kan plaatsvinden op dezelfde wijze als bij beveiliging tegen het onderscheppen van computergegevens, namelijk, door middel van het versleutelen van informatie. Specifiek voor de overheid is de invoering van art. 98/98a/98b WvS met betrekking tot misdrijven tegen de veiligheid van de staat

De procedure voor de accountant komt overeen met die van het onderscheppen van computergegevens. Ook adviezen met betrekking tot beveiliging tegen onbevoegde toegang kunnen van belang zijn.
Ad. 10 'Diefstal' van geautomatiseerde diensten

Charbon en Kaspersen (1990) verstaan onder 'diefstal' van geautomatiseerde diensten het zonder vergoeding gebruik maken van geautomatiseerde dienstverlening ${ }^{12}$ door manipulatie van toegangsmiddelen.

De accountant zal de schaderisico's nader onderzoeken en zal desgewenst adviezen uitbrengen met betrekking tot de toegangsbeveiliging tot de geautomatiseerde dienst, in de vorm van organisatorische maatregelen en procedures met betrekking tot administratieve organisatie en de daarmee verband houdende interne controle. Deze maatregelen en procedures moeten wel gezien worden in het licht van technische mogelijkheden en economische relevantie (kosten/baten).

De inhoud van paragraaf 3 is samengevat in Tabel 1 (zie pag. 622).

\section{Hoe kan de aandacht voor computer- criminaliteit ingepast worden in de accountantscontrole?}

Om de aandacht voor computercriminaliteit in te passen in de accountantscontrole zijn de belangrijkste punten het definiëren van de opdracht en de rapporteringsvorm.

\section{Definiëring van de opdracht}

De accountant stelt voor de jaarrekeningcontrole vooraf vast welke onderdelen van de geautomatiseerde informatieverwerking materiële invloed kunnen hebben op de jaarrekening. Voor verdergaande wensen van de cliënt heeft de accountant voorkeur voor het verkrijgen van een bijzondere opdracht. Met de cliënt stelt de accountant vooraf vast aan welke verschijningsvormen van computercriminaliteit in welke onderdelen van de geautomatiseerde informatieverwerking aandacht besteed moet worden. Dit kan uiteenlopen van nadruk op bepaalde te verwachten verschijningsvormen van computercriminaliteit tot het testen van het toegangspad ('hacken' op verzoek). Indien de 
Tabel 1: Categorisering van het begrip 'computercriminaliteit', de aansluiting met de Nederlandse wetgeving, de gevolgen van de onderscheiden verschijningsvormen van computercriminaliteit voor de cliënt en wat van de accountant verwacht mag worden

\begin{tabular}{|c|c|c|c|c|}
\hline \multicolumn{2}{|c|}{$\begin{array}{l}\text { Indeling naar de categorisering van de } \\
\text { Raad van Europa (gevolgd door Char- } \\
\text { bon/Kaspersen) }\end{array}$} & \multirow{2}{*}{$\begin{array}{l}\text { Wet } \\
\text { art. } 225 \text { WvS } \\
\text { art. } 232 \text { WvS }\end{array}$} & \multirow{2}{*}{$\begin{array}{l}\begin{array}{l}\text { Gevolgen voor } \\
\text { de cliënt }\end{array} \\
\text { (Financiële) } \\
\text { schade }\end{array}$} & \multirow{2}{*}{$\begin{array}{l}\text { Handelingen van } \\
\text { de accountant } \\
\text { Hanteren fraude- } \\
\text { richtlijn }\end{array}$} \\
\hline $1-2$ & $\begin{array}{l}\text { Computer-gerelateerde fraude } \\
\text { en valsheden }\end{array}$ & & & \\
\hline 3 & $\begin{array}{l}\text { Toebrengen van schade aan } \\
\text { (w.o. wijzigen van) computerge- } \\
\text { gevens en -programma's }\end{array}$ & $\frac{\underline{\operatorname{art}} 350 a-b}{\underline{W v S}}$ & $\begin{array}{l}\text { (Financiële) } \\
\text { schade }\end{array}$ & $\begin{array}{l}\text { Beoordelen } \\
\text { schade van } \\
\text { discontinuïteit }\end{array}$ \\
\hline 4 & Computersabotage & $\begin{array}{l}\text { art. } 161 \text { sexies- } \\
\text { senties WVS }\end{array}$ & $\begin{array}{l}\text { (Financiële) } \\
\text { schade }\end{array}$ & $\begin{array}{l}\text { Beoordelen } \\
\text { schade van } \\
\text { discontinuïteit }\end{array}$ \\
\hline 5 & Onbevoegde toegang & 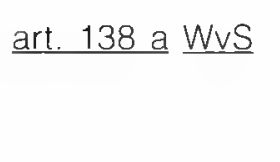 & Schade risico's & $\begin{array}{l}\text { Advies m.b.t. } \\
A O / I C \text { beveili- } \\
\text { ging + RE }\end{array}$ \\
\hline 6 & $\begin{array}{l}\text { Software piraterij: onbevoegd } \\
\text { gebruik maken van beschermde } \\
\text { programma's }\end{array}$ & Auteurswet & $\begin{array}{l}\text { Risico van } \\
\text { claims }\end{array}$ & $\begin{array}{l}\text { Frauderichtlijn en } \\
\text { waardering soft- } \\
\text { ware en mogelij- } \\
\text { ke claims }\end{array}$ \\
\hline 7 & $\begin{array}{l}\text { Onbevoegd onderscheppen van } \\
\text { computergegevens }\end{array}$ & $\begin{array}{l}\text { art. } 139 \text { a-e en } \\
\text { art. } 441 \text { WvS }\end{array}$ & Schade risico's & $\begin{array}{l}\text { Advies versleute- } \\
\text { len computerge- } \\
\text { gevens + RE }\end{array}$ \\
\hline 8 & Chips-piraterij & $\begin{array}{l}\text { Chipswet, Au- } \\
\text { teurswet }\end{array}$ & $\begin{array}{l}\text { Niet van toe- } \\
\text { passing }\end{array}$ & $\begin{array}{l}\text { Geen handelin- } \\
\text { gen }\end{array}$ \\
\hline 9 & Computerspionage & 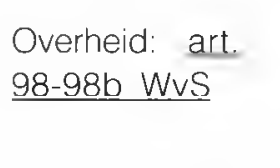 & $\begin{array}{l}\text { Financiële } \\
\text { schade }\end{array}$ & $\begin{array}{l}\text { Advies versleute- } \\
\text { len computerge- } \\
\text { gevens + RE }\end{array}$ \\
\hline 10 & $\begin{array}{l}\text { 'Diefstal' van geautomatiseerde } \\
\text { diensten }\end{array}$ & art. $326 c$ WVS & $\begin{array}{l}\text { Financiële } \\
\text { schade }\end{array}$ & $\begin{array}{l}\text { Advies m.b.t. } \\
\mathrm{AO/IC} \text { beveili- } \\
\text { ging + RE }\end{array}$ \\
\hline
\end{tabular}

\section{Toelichting}

$R E=$ het inschakelen van een Register EDP-auditor, indien de deskundigheid van de accountant tekort schiet. ${ }^{13}$

- $=$ de onderstreepte wetsartikelen in de tweede kolom hebben betrekking op de Wet computercriminaliteit. 
deskundigheid van de accountant tekortschiet, is het raadzaam extra EDP-deskundigheid in te huren. De verwachtingen die leven bij de cliënt kan de accountant kanaliseren door zijn taken en de reikwijdte van zijn werkzaamheden afdoende af te bakenen in zijn opdrachtbevestiging. Het kanaliseren van de verwachtingen kan versterkt worden door een duidelijk onderscheid te maken tussen wat de accountant ziet als algemene opdracht en bijzondere opdracht. Binnen het kader van de bijzondere opdracht kan de accountant komen tot maatwerk. Voor de opdrachtgever is het van belang om zich bewust te zijn van wat valt onder de wettelijke controleplicht en waar specifiek maatwerk vereist is in verband met de risico's van computercriminaliteit. Extra duidelijkheid over de diepte en strekking van de controle kan nooit kwaad.

Indien daarbij ook de verantwoordelijkheid van de cliënt voor het vóórkomen en het voorkómen van computercriminaliteit benadrukt wordt, is het risico van beroepsaansprakelijkheid voor de accountant te verkleinen.

De Wet Computercriminaliteit geldt niet expliciet voor de overheid, maar net zoals Boek 2 BW analoog wordt toegepast, zal binnen de overheidsaccountancy aandacht besteed worden aan verschijningsvormen van computercriminaliteit. De onafhankelijkheid van de overheidsaccountant wordt voornamelijk gewaarborgd door de (hoge) plaats in de organisatiestructuur. $\mathrm{Er}$ is geen sprake van een opdrachtbevestiging als zodanig. De jaarplannen van de overheidsaccountantsdiensten kunnen dienen als medium voor de opdrachtbevestiging.

\section{Rapporteringsvorm}

$\mathrm{Na}$ afronding van de (controle)werkzaamheden zal de accountant rapporteren over zijn bevindingen omtrent computercriminaliteit. Aan het bestuur en raad van commissarissen van de betreffende onderneming of instelling zal hij veelal rapporteren in de vorm van een managementletter. Dit zou te verwachten zijn, gezien de aandacht voor computercriminali- teit in de vorm van een wet. Maar zoals reeds besproken is in Hoofdstuk 2 verlangt de Wet Computercriminaliteit geen melding van bevindingen van computercriminaliteit, maar van de bevindingen van de accountant met betrekking tot de betrouwbaarheid en continuiteit van de geautomatiseerde gegevensverwerking. Hierbij is ogenschijnlijk een kwaliteitseis van het geautomatiseerde systeem binnen de jaarrekeningcontrole gehaald. Dit lijkt op meer werk voor de accountant. De minister van Justitie geeft echter duidelijk aan dat de accountant bij de jaarrekeningcontrole in aanraking komt met de administratieve organisatie en de interne controle van de onderneming (nota naar aanleiding van het eindverslag, Kamerstukken II 1989-1992, 21551 nr. 11 p. 16). Langs die weg zal hij ook de geautomatiseerde gegevensverwerking onderzoeken, voor zover dat noodzakelijk is voor de jaarrekeningcontrole. Voor zover er dan bijzonderheden blijken, zullen deze moeten worden vermeld in het verslag. Zijn er geen bevindingen dan wordt dat vermeld. Of er dan gepaste actie ondernomen wordt is verder aan het bestuur en/of de raad van commissarissen. De minister van Justitie stelt vervolgens duidelijk dat het onderzoek van de jaarrekening op zichzelf niet gericht is op de betrouwbaarheid en continuiteit van de geautomatiseerde gegevensverwerking. Het onderzoek naar de jaarrekening kan daarom onvoldoende materiaal opleveren. De accountant kan dat in het kader van de bevindingen vermelden. Wettelijk verplicht is die vermelding niet eens. Een volkomen onderzoek naar de betrouwbaarheid en continuïteit van het geautomatiseerde systeem wordt absoluut niet geëist. De Wet Computercriminaliteit verwacht niets méér van de accountant dan wat van een goede accountant verwacht mag worden.

Richting het maatschappelijk verkeer kan de accountant rapporteren in de vorm van een mededeling of verklaring. Voor rapportering aan het maatschappelijke verkeer en voor bijzondere opdrachten zijn geen specifieke wettelijke eisen gesteld. 


\section{Conclusies}

Aandacht voor computercriminaliteit levert voor de accountant op zich geen nieuw soort handelingen op, aangezien hij dit kan vertalen naar handelingen die hij reeds kent.

Van de accountant mag verwacht worden dat hij bij zijn jaarrekeningcontrole terloops geconstateerde verschijningsvormen van computercriminaliteit (met name die met materiële financiële consequenties) zal onderzoeken of zal laten onderzoeken

De opdrachtbevestiging is een belangrijk instrument om de verantwoordelijkheden voor de accountant met betrekking tot computercriminaliteit te verduidelijken, de verwachtingen

van de cliënt te kanaliseren en het risico van beroepsaansprakelijkheid te beperken

De Wet Computercriminaliteit heeft voor de accountant de extra wettelijke eis ingesteld. om aan zijn cliënt te rapporteren indien hij bij zijn controle van de jaarrekening bevindingen heeft die gaan over de betrouwbaarheid en continuilteit van de geautomatiseerde gegevensverwerking

In feite wordt de accountant wettelijk verplicht te rapporteren over bevindingen die hij gedaan heeft in het kader van de jaarrekeningcontrole.

Heeft een accountant delen van de automatisering niet in de jaarrekeningcontrole meegenomen, omdat dat buiten het kader van zijn onderzoek valt, dan kan hij daarover geen bevindingen hebben. Rapporteren over iets wat buiten de controle-opdracht valt, is uiteraard niet verplicht. Een goede accountant is reeds gewend aan zijn cliënt te rapporteren over zijn bevindingen.

$\mathrm{Er}$ is niets nieuws onder de zon.

Indien de opdrachtgever wil dat de accountant meer onderzoek verricht dan (volgens de Wet Computercriminaliteit) wettelijk vereist is, heeft de accountant voorkeur dat dit kan geschieden in de vorm van een bijzondere opdracht, die losstaat van de algemene jaarrekeningcontrole. Op deze wijze is binnen het kader van de bijzondere opdracht maatwerk mogelijk.

\section{Literatuur}

F.H. Charbon, H.W.K. Kaspersen (1990), Computercriminaliteit in Nederland. Den Haag: Stichting Beheer Platform Computercrimınaliteit

Commissie Computercriminaliteit (1987), Informatietechniek en strafrecht

Centrale Recherche Informatiedienst, sectie Computercriminaliteit (1991), Computervirussen, Den Haag.

NIVRA (1982), Automatisering en controle deel IV. Mededelingen door de accountant met betrekking tot de betrouwbaarheid en continuilteit van geautomatiseerde informatieverwerking, NIVRA-geschrift 26

NIVRA (1989). Automatisering en controle VII. Kwaliteitsoordelen over informatievoorzlening, NIVRA-geschrift 53

Wetsontwerp Computercriminaliteit, Kamerstukken II 1989. 1992, $21551 \mathrm{nr} .1 \mathrm{t} / \mathrm{m} 13$

Wet Computercriminaliteit, Staatsblad 199333

\section{Noten}

1 Materieel strafrecht stelt wat strafbaar is; formeel strafrecht regelt de strafvordering

$2 \mathrm{Om}$ de aangiftebereidheid te vergroten is op instigatie van de Commissie Computercriminaliteit (1987 p. 101) het Platform Computercriminaliteit in het leven geroepen, waar een geanonimiseerde vorm van aangifte gedaan kan worden

3 Trouwens is dit volledig in overeenstemming met de terminologie die bij het NIVRA gebruikelijk is/was: NIVRAgeschrift 26 was van 1982; het rapport van de Commissie Franken is gedateerd op april 1987 en NIVRA-geschrift 53 is van 1989

4 Voor de exacte formulering van de delicten wordt verwezen naar de wettekst (Stb. 1993 33)

5 Een virus is een (klein) programma dat in een ander programma wordt geplaatst (of in enkele gevallen in eerste aanleg geheel op zichzelf staat) en dat vervolgens in staat is om een kopie van zichzelf in een ander programma of op een andere schijf te plaatsen. Een virus brengt in het algemeen beschadigingen aan in bestanden, programma's of kan ze zelfs volledig wissen. (Bron: Charbon en Kaspersen (1990) p. 55)

6 Een Trojaans paard is een (onbevoegde) programmamanipulatie waarbij instructies worden toegevoegd aan een computerprogramma, die andere activiteiten initiëren dan die waartoe het programma door de gebruiker in werking wordt gesteld. Een Trojaans paard kopieert zichzelf niet en plaatst zich niet in een ander programma. (Bron: Charbon en Kaspersen (1990) p. 55)

7 Een logische bom is een programma, onbevoegd ingebouwd in een geautomatiseerd systeem, dat op een bepaald moment, bij een bepaalde gebeurtenis, of op geregelde tijdstippen, een bepaalde actie uitvoert. Een logische bom kopieert zichzelf niet en is in feite een Trojaans paard dat alleen bij een bepaalde conditie in werking treedt. (Bron: Charbon en Kaspersen (1990) p. 55). 8 Een worm is een programma dat zichzelf kopieert, zonder 


\section{MAR}

hulp van buitenaf en dat in principe geen verdere (vernietigings)instructies bevat. Door de verspreiding neemt het na verloop van tijd dermate veel capaciteit in beslag dat het geautomatiseerde systeem niet meer behoorlijk kan functioneren, of in ieder geval ernstig wordt vertraagd.

(Bron: Charbon en Kaspersen (1990) p. 55).

9 Onder sabotage door middel van 'logische' middelen wordt sabotage verstaan door middel van manipulaties van computergegevens en/of -programma's.

10 Gedoeld wordt op 'reverse engineering', het aan de hand van de chip zelf het ontwerp terugontwikkelen, hetgeen veel in Zuid-oost Azië plaatsvindt.

$11 \mathrm{Bij}$ het Platform Computercriminaliteit worden dezelfde verschijningsvormen van computercriminaliteit onderscheiden als bij Charbon en Kaspersen (1990), behalve de verschijningsvorm 'computerspionage' (Centrale Recherche Informatiedienst (1991) p. 10)

12 Voorbeelden hiervan zijn:

- het manipuleren van autotelefoons, zodanig dat gesprekskosten aan een derde in rekening worden gebracht;

- inbreken in een Viditelsysteem of

- het, op kosten van een ander, gebruik maken van de functies van een computersysteem (bijvoorbeeld databanken).(Bron: Charbon en Kaspersen (1990) p. 122).

13 De Register EDP-auditor van NOREA wordt hier bedoeld, mede omdat NOREA erkend is door het NIVRA als toonaangevende organisatie in verband met het onder gemeenschappelijke naam optreden. 